\title{
Long Term Sequelae of West Nile Neuroinvasive Disease in a 36
}

\section{Years Old Woman}

\section{Authors}

\begin{tabular}{lll}
\hline Name & Affiliation & Contributions \\
\hline $\begin{array}{l}\text { Muhammad Ali } \\
\text { Corresponding author }\end{array}$ & Awan Clinic, Faisalabad & $\frac{\text { m.alinaeem23@ gmail.com; }}{\text { alinaeem023@ @otmail.com; }}$ \\
\hline $\begin{array}{l}\text { Muhammad Haider, } \\
\text { MBBS }\end{array}$ & DHQ Hospital, Faisalabad & $\underline{\text { mhaider0117@gmail.com; }}$ \\
\hline Naeem Akhtar, MBBS & Awan Clinic, Faisalabad & drnaeemawan58@gmail.com;
\end{tabular}

\section{Abstract Summary:}

A case report of the diagnosis of Long Term Sequelae of West Nile Neuroinvasive Disease in a patient with 9 years history. Empirical data of symptoms and test reports has been presented and based on the available data likely pathogenesis of the disease has been discussed. The empirical data has been compared to the published literature to reach a highly confident diagnosis.

\section{Keywords:}

Neurology; Neuroinvasive Disease; Encephalitis; Meningitis; MRI Brain Scans; West-Nile Virus; Infectious Diseases; Diagnostic Tools 


\section{Case Presentation:}

A 36 years old woman patient presented with cognitive dysfunction; having severe memory impairment, defects in verbal and visuospatial learning and lack of motor control. The patient had rather remarkable 9 years old history. Patient's attendant (mother), presented the symptoms from 9 years, which included fever, headache, body aches and neck stiffness. Furthermore, during that time, patient was under significant stress, resulting from the fact that she was due to be married in couple of weeks. Following these symptoms, the patient was found lying unconscious on the bathroom floor. She was taken to the hospital, where she had high fever and seizures, followed by coma. Once she regained wakefulness, she was in vegetative state for about a month. During this time, several diagnostic tests were performed, which are summarized in Table 1. Once the patient regained partial awareness, she had extreme memory loss and she had to undergo physiotherapy to learn partial motor control. Following that, she continued to have epileptic seizures and showed depressive tendencies, for years. Her verbal and visuospatial learning slightly improved but currently she is still unable to carry out basic human activities independently. 


\begin{tabular}{|c|c|c|c|c|}
\hline Date & Diagnostic Test & Protocol & Results & Remarks \\
\hline $\begin{array}{l}23-01- \\
2012\end{array}$ & $\begin{array}{l}\text { CT Scan of } \\
\text { Brain (Plain } \\
\text { Axial scans) }\end{array}$ & Scanning & $\begin{array}{l}\text { No evidence of intra cranial } \\
\text { bleed, mass or gross area } \\
\text { infraction. Normal grey and } \\
\text { white matter differentiation }\end{array}$ & $\begin{array}{l}\text { Diagnostically } \\
\text { Insignificant }\end{array}$ \\
\hline $\begin{array}{l}25-01- \\
2012\end{array}$ & $\begin{array}{l}\text { MRI of the } \\
\text { Brain }\end{array}$ & Scanning & $\begin{array}{l}\text { Evidence of abnormal } \\
\text { signals seen with bilateral } \\
\text { frontal, parietal, occipital } \\
\text { and temporal regions. These } \\
\text { signals hyperintense on T2 } \\
\text { weighted images and Flair } \\
\text { images and isointense to } \\
\text { hypointense on T1 weighted } \\
\text { images. Involvement of } \\
\text { bilateral head of caudate } \\
\text { nuclei and basal ganglian } \\
\text { region. } \\
\text { No evidence to suggest } \\
\text { intracranial bleed or mass. }\end{array}$ & $\begin{array}{l}\text { Possibility of these } \\
\text { changes secondary } \\
\text { to diffuse and } \\
\text { disseminated } \\
\text { Encephalomyelitis. } \\
\text { Clinical } \\
\text { correlations } \\
\text { advised }\end{array}$ \\
\hline $\begin{array}{l}27-01- \\
2012\end{array}$ & $\begin{array}{l}\text { Ultasound } \\
\text { (Whole } \\
\text { Abdomen) }\end{array}$ & N/A & $\begin{array}{l}\text { Normal. } \\
\text { No evidence of ascites and } \\
\text { lymphadenopathy. } \\
\text { No pleural effusion on either } \\
\text { side } \\
\text { No abnormal segment of } \\
\text { bowel loop noted in either } \\
\text { iliac fossa }\end{array}$ & $\begin{array}{l}\text { Diagnostically } \\
\text { insignificant }\end{array}$ \\
\hline $\begin{array}{l}01-02- \\
2012\end{array}$ & $\begin{array}{l}\text { MRI Lumbo- } \\
\text { Sacral Spine }\end{array}$ & Screening & $\begin{array}{l}\text { Loss of normal lordosis } \\
\text { likely due to muscular } \\
\text { spasm. } \\
\text { Disc Dehydration identified } \\
\text { at L4/L5 level. } \\
\text { Associated circumferential } \\
\text { disc bulge with annular tear } \\
\text { identified at L4/L5 level } \\
\text { causing mild compression } \\
\text { over thecal sac and bilateral } \\
\text { neural foraminal narrowing } \\
\text { with encroachment upon } \\
\text { exiting nerves. } \\
\text { Mild central disc protrusion } \\
\text { identified at L5/S1 level } \\
\text { causing mild indentation } \\
\text { over thecal sac without } \\
\text { neural foraminal narrowing. }\end{array}$ & $\begin{array}{l}\text { Clinical } \\
\text { correlations } \\
\text { recommended. } \\
\text { Does not guarantee } \\
\text { absence of lesion } \\
\text { or disease. }\end{array}$ \\
\hline $\begin{array}{l}01-02- \\
2012\end{array}$ & $\begin{array}{l}\text { MRI Cervical } \\
\text { Spine }\end{array}$ & Screening & $\begin{array}{l}\text { Loss of normal cervical } \\
\text { lordosis like due to muscular } \\
\text { spasm }\end{array}$ & $\begin{array}{l}\text { Clinical } \\
\text { correlations } \\
\text { recommended. } \\
\text { Does not guarantee }\end{array}$ \\
\hline
\end{tabular}




\begin{tabular}{|l|l|l|l|l|}
\hline $\begin{array}{l}\text { 07-02- } \\
2012\end{array}$ & $\begin{array}{l}\text { Ultasound } \\
\text { (Whole } \\
\text { Abdomen) }\end{array}$ & N/A & Normal & $\begin{array}{l}\text { absence of lesion } \\
\text { or disease. }\end{array}$ \\
\hline $\begin{array}{l}18-04- \\
2012\end{array}$ & $\begin{array}{l}\text { MRI of the } \\
\text { Brain }\end{array}$ & Screening & $\begin{array}{l}\text { Diagnostically } \\
\text { insignificant } \\
\text { with dilatation of the } \\
\text { ventricles and cortical suclei } \\
\text { are seen. } \\
\text { Few small focal regions of } \\
\text { abnormal signal seen in } \\
\text { periventricular basal ganglia } \\
\text { region. } \\
\text { No evidence of abnormal } \\
\text { signal in brain to suggest } \\
\text { intracranical bleed or mass. }\end{array}$ & $\begin{array}{l}\text { Clinical } \\
\text { recommended }\end{array}$ \\
\hline $10-12-$ & $\begin{array}{l}\text { MRI of the } \\
\text { Brain }\end{array}$ & Scanning & $\begin{array}{l}\text { Marked cortical atrophy } \\
\text { with dilatation of the } \\
\text { ventricles and cortical suclei } \\
\text { are seen. } \\
\text { Cortical and subcortical } \\
\text { areas of abnormal signal } \\
\text { intensity are also seen within } \\
\text { the bilateral temporal cortex, } \\
\text { bilateral frontal and parietal } \\
\text { cortex and temporo-occipital } \\
\text { cortex on the right side. }\end{array}$ & $\begin{array}{l}\text { Possibility of these } \\
\text { changes being } \\
\text { secondary to a } \\
\text { neurodegenerative } \\
\text { disorder or gliosis } \\
\text { secondary to } \\
\text { previous } \\
\text { encephalitis or } \\
\text { ischemia. } \\
\text { Clinical } \\
\text { correlation } \\
\text { recommended. }\end{array}$ \\
\hline
\end{tabular}

Table 1: Timeline, results and remarks of Diagnostic Tests performed on the Patient

\section{Discussion}

Based on the empirical data, it is very likely that the patient is suffering from a severe longterm sequelae of West Nile Neuroinvasive Disease (WNND). The initial symptoms and progression of symptoms from 9 years ago points towards West Nile viral infection with central nervous system (CNS) complications, which occur in about 1 in 150 clinically apparent infections ${ }^{1}$ and results in long-term cognitive and neurological impairment in the survivors ${ }^{1}$. In this case, the certainty of definitive diagnosis is significantly reduced, because of prolonged time span of the case and lack of data. To reach a confident diagnosis, one has to rely heavily 
on indirect evidence from literature and the available empirical data. To serve this purpose, a likely pathogenesis of WNND in the patient is established shown in Figure 1. MRI scans of brain dated 25-01-2012 (Table 1) likely shows patient's brain, while still infected by WNV. MRI results of the patient matches with the MRI results of a patient with WNV in a published literature $^{2}$. In both patients, FLAIR images and T2 weighted images (T2WI) showed hyperintense abnormal signals in frontal, parietal, occipital and temporal regions and T1 weighted images (T1W1) showed weak signals. The patient from the study ${ }^{2}$ had severe neurologic deficits, which matches the profile of the patient of this study. Furthermore, in that study, it was concluded that WNV patients with abnormal signal intensity in T2WI and FLAIR images had worst outcome. Furthermore, other studies ${ }^{3-5}$ concludes that approximately half of WNND survivors experience long term cognitive sequelae, which includes memory loss, depression, confusion, verbal and visuospatial learning, which matches the symptoms profile of patient of this study. It has been determined that WNV targets neurons and causes synapse loss in humans, in vivo ${ }^{6,7}$. This explains the cortical atrophy in the brain MRIs of the patients dated 18-04-2012 and 10-12-2014 (Table 1). These brain MRI scans are likely after the viral clearance from the patient and show sequelae of WNND, likely caused by cytokine storm. This can be explained by the inflammatory events triggered by the production of cytokines by astrocytes and microglia cell as an immune response against WNV. It has been suggested that during acute phase of WNV infection, myeloid cell-derived IL-1 alters the proliferation and differentiation fates of neural progenitor cells, leading to a transition from neurogenesis to astrogenesis $^{8}$, preventing the neuronal repair. Infection causes the alterations in the expression of gene encoding molecules limiting neurogenesis. Astrocytes produced through astrogenesis than becomes predominant source of cytokines, which continue to inhibit neurogenesis, after myeloid cells retreat from the $\mathrm{CNS}^{7}$. The combined effect of synapse loss ${ }^{7}$ and reduced neurogenesis then affects spatial learning and memory loss beyond infection ${ }^{8}$. There is a shift 
in the sources of cytokines to neural cells, after the infection, preventing neuronal repair, which likely results in cortical atrophy shown in patients MRI scans of the brain.

Based on the above discussion, one can reach a confident diagnosis that the patient is suffering from the Long-term sequelae of West Nile Neuroinvasive disease. It is a unique case, as it shows significant effects of disease 9 years beyond the onset. Furthermore, it shows the significance of symptoms profiling with the literature, which is an effective diagnostic tool for diagnosticians especially in underdeveloped and developing countries which testing capabilities are scarce.

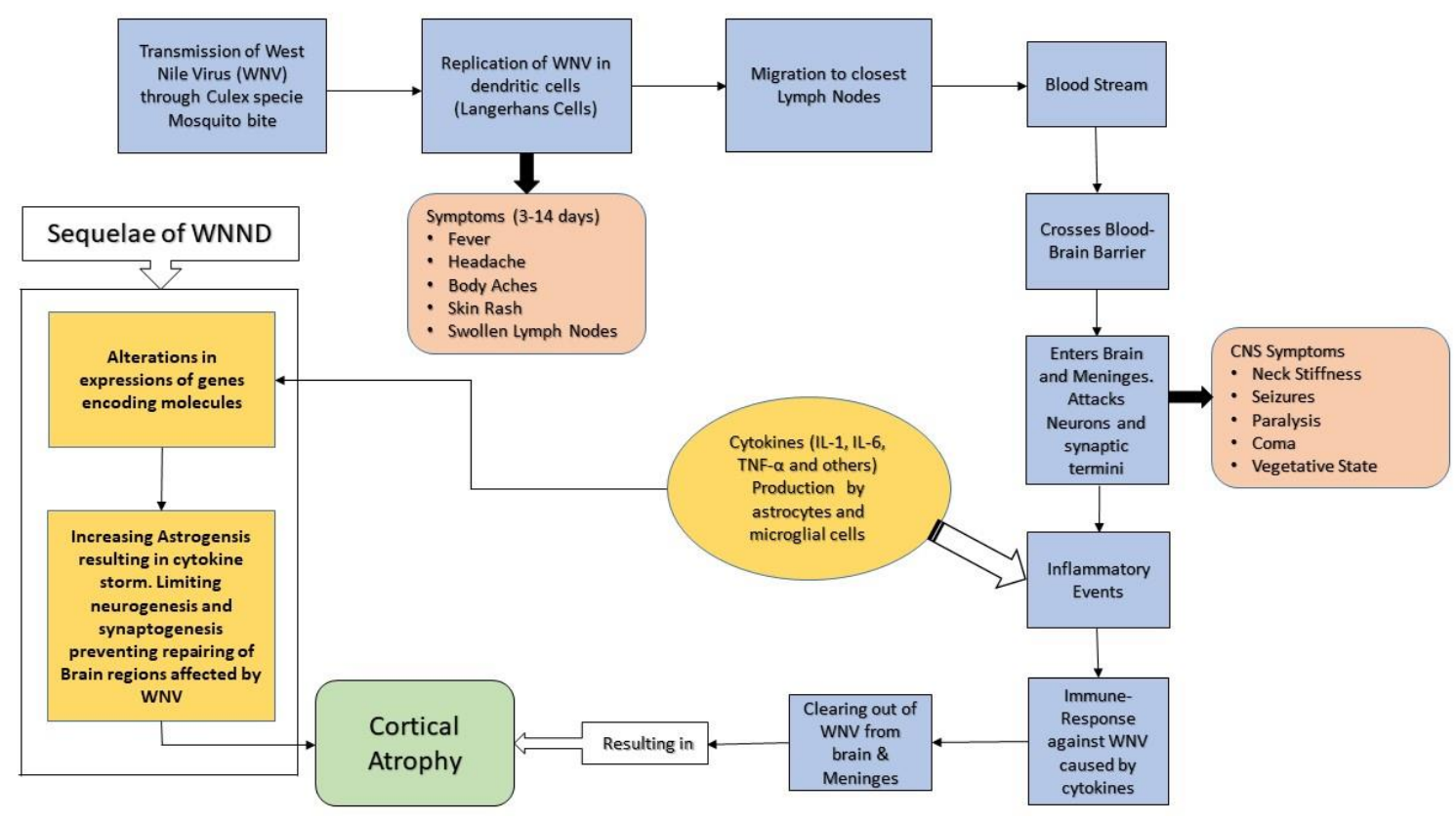

Figure 1. Likely Pathogenesis of West Nile Neuroinvasive Disease in the Patient 


\section{References}

1. Kumar V, Abbas AK, Aster JC. Robbins \& Cotran Pathologic Basis of Disease, 9th ed. Canada: Elsevier, 2014.

2. Ali M, Safriel Y, Sohi J, et al. West Nile Virus Infection: MR Imaging Findings in the Nervous System. American Journal of Neuroradiology Feb 2005; 26 (2) 289-297.

3. Salimi H, Cain MD, Klein RS. Encephalitic arboviruses: emergence, clinical presentation, and neuropathogenesis. Neurotherapeutics 2016;13, 514-534 .

4. Lambert SL, Aviles D, Vehaskari VM, Ashoor IF. Severe West Nile virus meningoencephalitis in a pediatric renal transplant recipient: successful recovery and long-term neuropsychological outcome. Pediatr. Transplant 2016;20, 836-839.

5. Patel H, Sander B, Nelder MP. Long-term sequelae of West Nile virus-related illness: a systematic review. Lancet. Infect. Dis. 2015;15, 951-959.

6. Guarner J, et al. Clinicopathologic study and laboratory diagnosis of 23 cases with West Nile virus encephalomyelitis. Hum. Pathol. 2004; 35, 983-990.

7. Vasek MJ, et al. A complement-microglial axis drives synapse loss during virusinduced memory impairment. Nature 2016; 534, 538-543.

8. Garber $\mathrm{C}$, et al. Astrocytes decrease adult neurogenesis during virus-induced memory dysfunction via IL-1. Nat Immunol. 2018 Feb;19(2):151-161. 